\title{
CRITICAL REVIEW OF PHYSICAL MODELLING OF SNOW ACCUMULATION ON ROOFS WITH ARBITRARY GEOMETRY
}

\author{
Alexander M. Belostotsky ${ }^{1,2,3}$, Oleg S. Goryachevsky ${ }^{1,2}$, Nikita A. Britikov ${ }^{2,3}$ \\ ${ }^{1}$ Scientific Research Center StaDyO, Moscow, RUSSIA \\ ${ }^{2}$ National Research Moscow State University of Civil Engineering, Moscow, RUSSIA \\ ${ }^{3}$ Russian University of Transport (RUT-MIIT), Moscow, RUSSIA
}

\begin{abstract}
A review of the most significant domestic and, due to numerical superiority, foreign works on physical modelling of snow transport and snow accumulation processes, in particular, for the purpose of determining snow loads on roofs with arbitrary geometry, is presented. The existing practice of development of recommendations on assignment of snow loads in Russian laboratories is considered and critically evaluated. Comparison of do-mestic works with scientific articles in the advanced world scientific journals and foreign regulatory documents leads to unfavorable conclusions. Recommendations on assigning snow loads, issued by Russian laboratories on the basis of extremely outdated and poorly substantiated methodology, bear a serious risk for evaluating mechan-ical safety of modern structures, for which such recommendations are developed. Recommendations are offered to remedy this current dangerous practice. The article also gives some suggestions on forming a basis for field observations of snow loads on existing roofs.
\end{abstract}

Keywords: physical modeling, wind tunnel, water flume, snow accumulation, structure roofs.

\section{МЕТОДЫ ФИЗИЧЕСКОГО МОДЕЛИРОВАНИЯ СНЕГОНАКОПЛЕНИЯ НА ПОКРЫТИЯХ СООРУЖЕНИЙ ПРОИЗВОЛЬНОЙ ФОРМЫ КРИТИЧЕСКИЙ ОБЗОР}

\author{
А.М. Белостоцкий ${ }^{1,2,3}$ О.С. Горячевский ${ }^{1,2}$, Н.А. Бритиков ${ }^{2,3}$ \\ ${ }^{1}$ Научно-исследовательский центр СтаДиО, г. Москва, РОССИЯ \\ ${ }^{2}$ Национальный исследовательский Московский государственный строительный университет, \\ г. Москва, РОССИЯ \\ ${ }^{3}$ Российский университет транспорта (МИИТ), г. Москва, РОССИЯ
}

\begin{abstract}
Аннотация: Представлен обзор наиболее значимых отечественных и, по вынужденному преимуществу, иностранных работ по физическому моделированию процессов снегопереноса и снегонакопления, в частности, для целей определения снеговых нагрузок на покрытия сооружений произвольной формы. Рассматривается и критический оценивается существующая практика разработки рекомендаций по назначению снеговых нагрузок в российских лабораториях. Сравнение отечественных работ с научными статьями в передовых мировых научных изданиях и иностранными нормативными документами приводит к неутешительным выводам. Рекомендации по назначению снеговых нагрузок, выдаваемые российскими лабораториями на основе крайне устаревшей и плохо обоснованной методики, несут серьезный риск для оценки механической безопасности современных сооружений, для которых такие рекомендации разрабатываются. Предложены рекомендации для исправления этой сложившейся опасной практики. В статье также даются некоторые предложения по формированию базы натурных наблюдений снеговых нагрузок на существующих покрытиях.
\end{abstract}

Ключевые слова: физическое моделирование, аэродинамическая труба, экспериментальный водосток, снегонакопление, покрытия сооружений. 


\section{INTRODUCTION}

At present, the most widespread approach in Russia and abroad to determining snow loads on roofs with arbitrary geometry is physical simulation of snow accumulation in a wind tunnel (hereinafter, WT) or a water flume. Despite the long history of the issue, among the domestic publications there are no full-fledged review studies sufficiently covering the historical and modern practices. Such an information vacuum in the Russian scientific field creates prerequisites for oversimplification and distortion of the methods of relevant experiments developed, tested and time-proven in advanced scientific laboratories of the world. Unfortunately, domestic laboratories actively use these prerequisites of general ignorance, which carries significant risks for the adequate assessment of the mechanical safety of unique and critical structures, for which the corresponding research is conducted. The authors hope that this article will direct the development of domestic techniques for physical modelling of snow accumulation towards the implementation of best scientific practices.

Apparently, one of the first scientists to conduct large-scale physical experiments to simulate snow drift and compare them with field data was Finney [1] in 1934. His experiments to simulate snow transport near road barriers were carried out at an intuitive level. Similarity issues, cohesion of the snow-like material, wind profile and other important modelling subtleties were not addressed in the study.

The greatest contribution to the development of physical modelling of snow accumulation and snow drift, including on roofs of buildings and structures, was made by foreign scientists: Anno [2-4], Irwin [5-7], Iversen [8-9], Kind [10-11], Odar [12-13] and Izyumov [14-15]. This list of authors and their works is far from complete.

There are only a few Russian papers on the subject matter of this article. Some of them focus on field measurements and the creation of snow zoning maps [51-55]. Another part of works is devoted directly to snow loads on roofs [57-59].
It should be noted that only a few papers $[52,55]$ are of a high scientific level and the other ones are either reports or blatant compilations (the paper [56] is simply a translation of the corresponding chapter of the ASCE standard [19], even without referencing the original source).

\section{MAIN APPROACHES TO PHYSICAL MODELLING OF SNOW ACCUMULATION}

One of the most extensive studies of determin-ing the snow loads, including a synthesis of previous accumulated experience, many new experiments and scientific conclusions, was carried out as part of the Eurocode development $[17,18]$. The study elaborates in detail the improvement of snow zoning maps of European territories, assignment of load combination coefficients (including snow load), and distribution of snow loads on the roofs of buildings and structures. As far as the snow load distribution is concerned, much attention is given to description of the field measurements performed, large-scale experiments at the climatic WT (CSTB, France) and details of processing the results. A thorough description of the conditions and the results of many experiments in graphical (photos, graphs, diagrams, etc.) and tabular form make this study a kind of reference book, which can be used as a basis for one's own research.

The study $[17,18]$ clearly and unambiguously shows that it is very difficult to carry out field observations of snow loads on the roofs of buildings. A sufficiently large sample of data is necessary for the correct statistical processing of the results and the determination of dependencies. Snow loads are influenced not only by the geometry of the building (controllable parameter), but also by climatic factors (uncontrollable parameters) and landscape (partially controllable parameters), so multi-year studies in different climatic zones and landscapes are necessary. Unfortunately, a study $[17,18]$ of snow load distributions on the roofs of buildings located near weather stations in several European countries was conducted only for one season. Many of the field data proved to 
be unrepresentative due to low snowfall winters in the respective areas, unfortunate location selection and other reasons. The data obtained did not allow to conduct a full regression analysis to determine the dependence of the shape coefficient on climatic factors and the geometry of the building. Nevertheless, dependencies of shape coefficient on roof pitch, wind speed and ambient temperature were obtained with satisfactory reliability.

Due to the aforementioned shortcomings, field experiments do not allow the distribution of snow loads on different roof shapes to be fully normalized. The main data for the normalization of the shape coefficient $\mu$ [19] was obtained through experiments in the CSTB climatic WT. The CSTB climatic WT experiments were performed with fairly large scale models (1:10) and real snow generated by a snow cannon (Fig. 1). Different temperature and humidity regimes and two characteristic wind regimes were considered

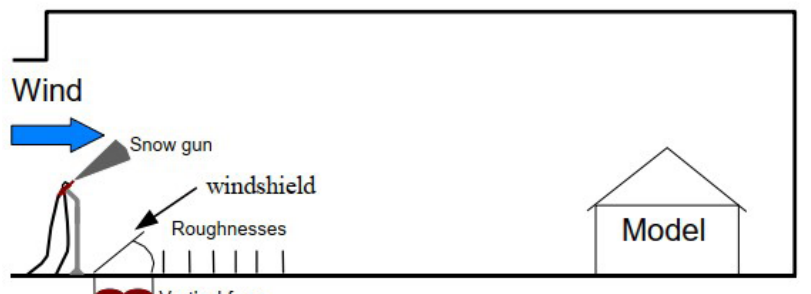

a)

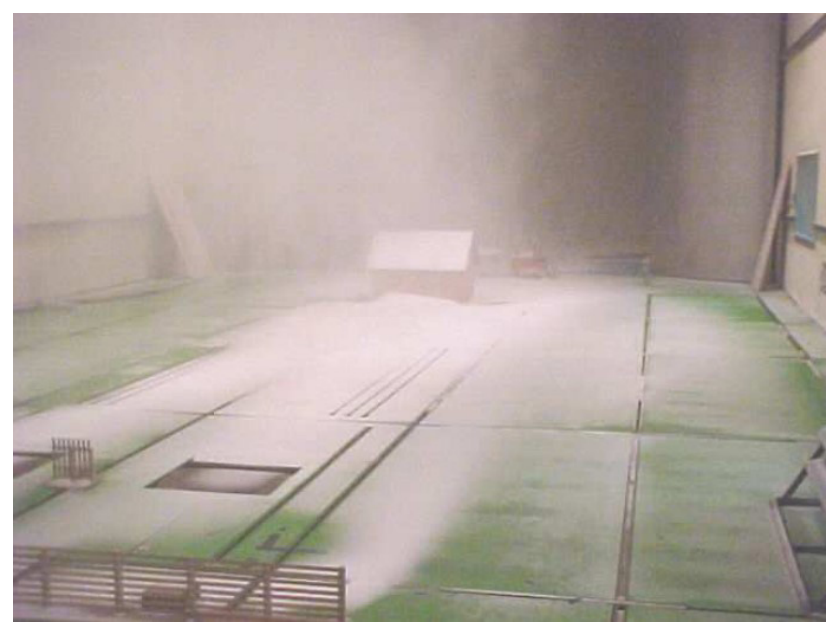

b)

Figure 1. a) Diagram of an experimental setup for simulating snow loads; b) photograph of the experiment process [18]

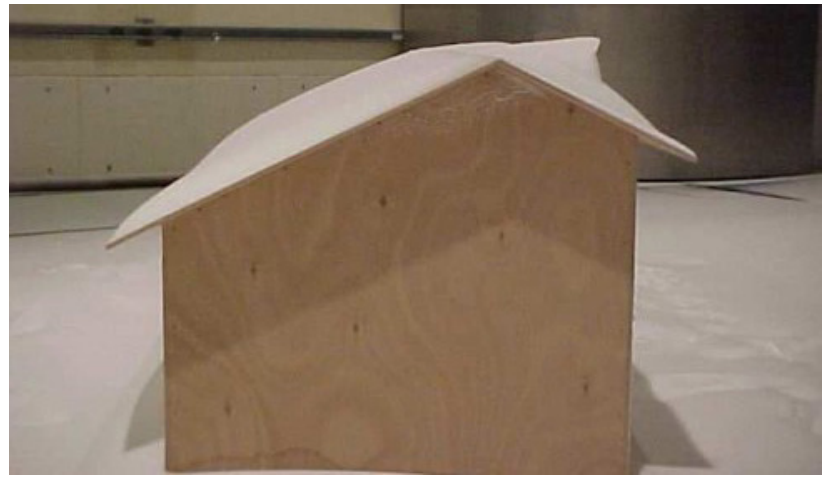

a) gable roof with lantern and extended edges

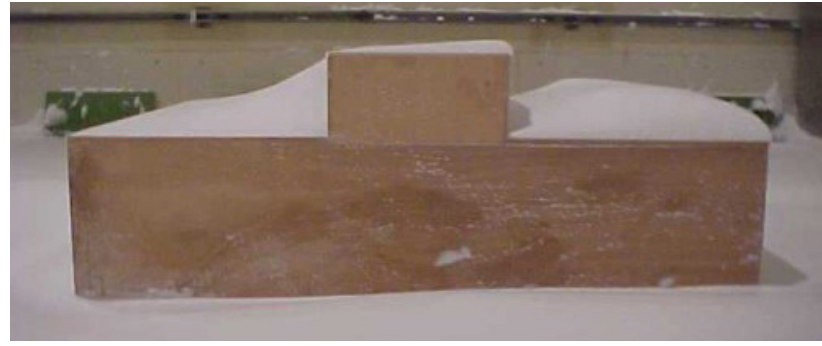

b) multi-level roof

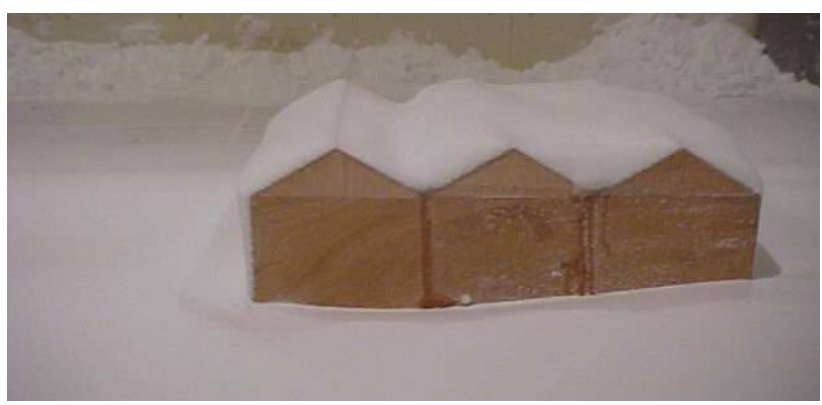

c) multi-span gable roof

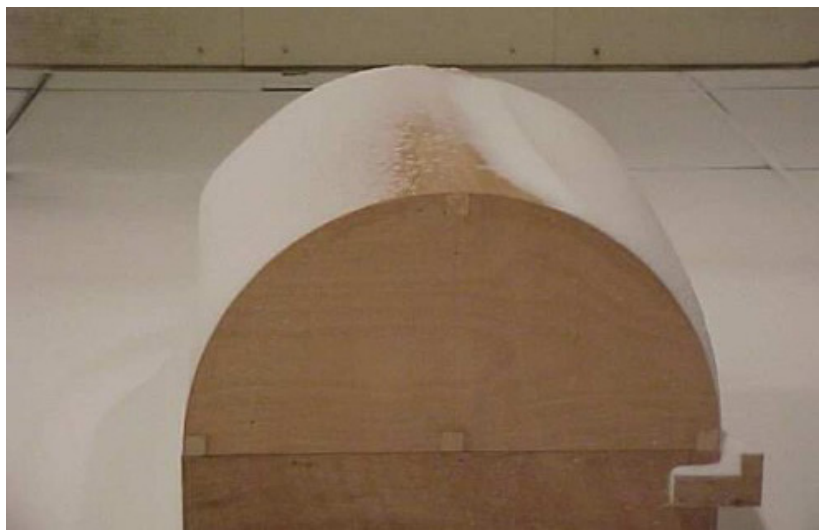

d) cylindrical roof

Figure 2. The results of physical modeling of snow loads in the climatic WT CSTB [18] 
(windless weather and snow storm were simulated). This approach made it possible to obtain physical pictures of snow distribution (Fig. 2), which distinguishes these experiments from domestic works on experimental determination of the shape coefficient on complex roofs carried out as part of scientific and technical support for construction. The small scale (usually 1:300), the use of snowlike material, and modelling only the entrainment of material without modelling snowfall, result in snow load distribution patterns that obviously have nothing to do with reality (Fig. 3).
One of the important conclusions of the study [18] is the experimental confirmation that the snow density on the building roof is quite strongly dependent on the location (windward or leeward), that is, wind pressure tamps the snow. It is not possible to take this factor into account adequately with snow substitutes.

Large-scale experiments to simulate snow transport and snow deposition fall into two major categories [20]:

1. Particle methods. Experiments are conducted in WTs or special water flumes. The essence of the

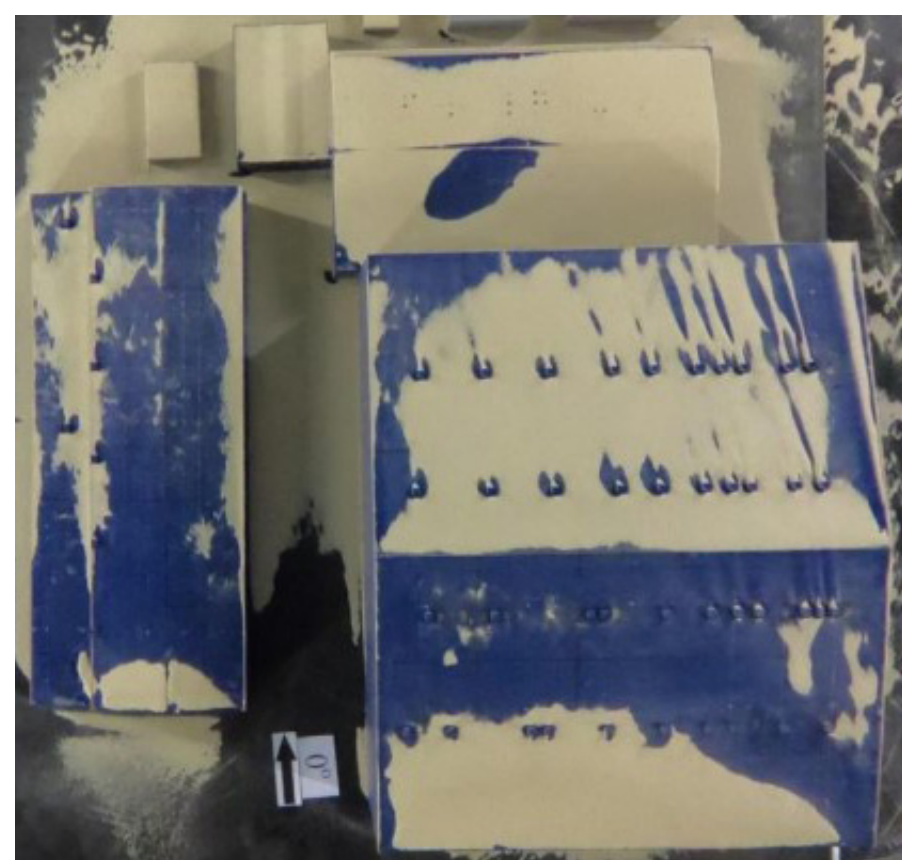

a) UNIKON

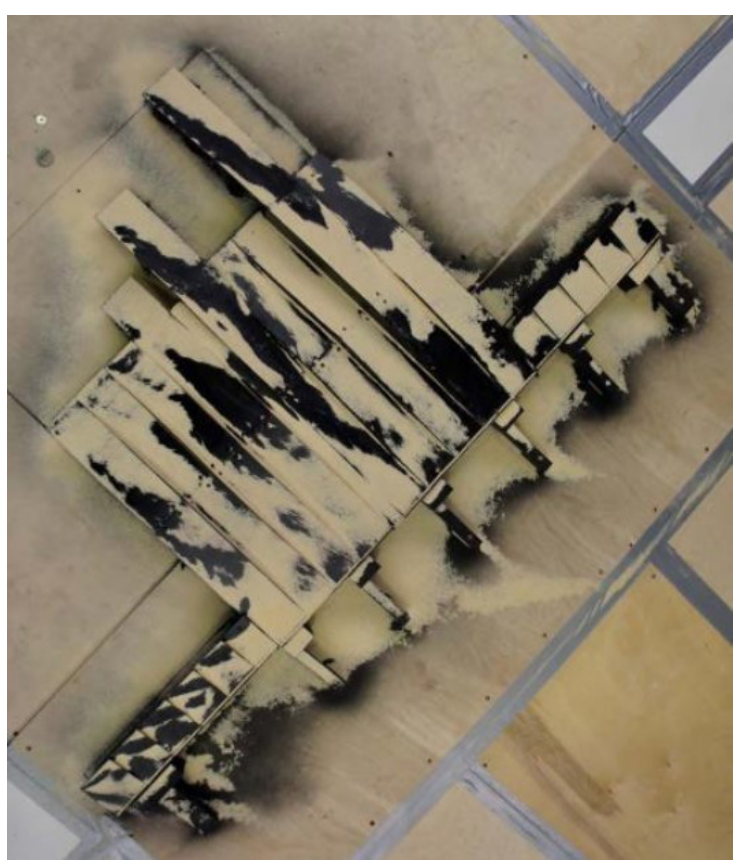

b) National Research Moscow State University of Civil Engineering

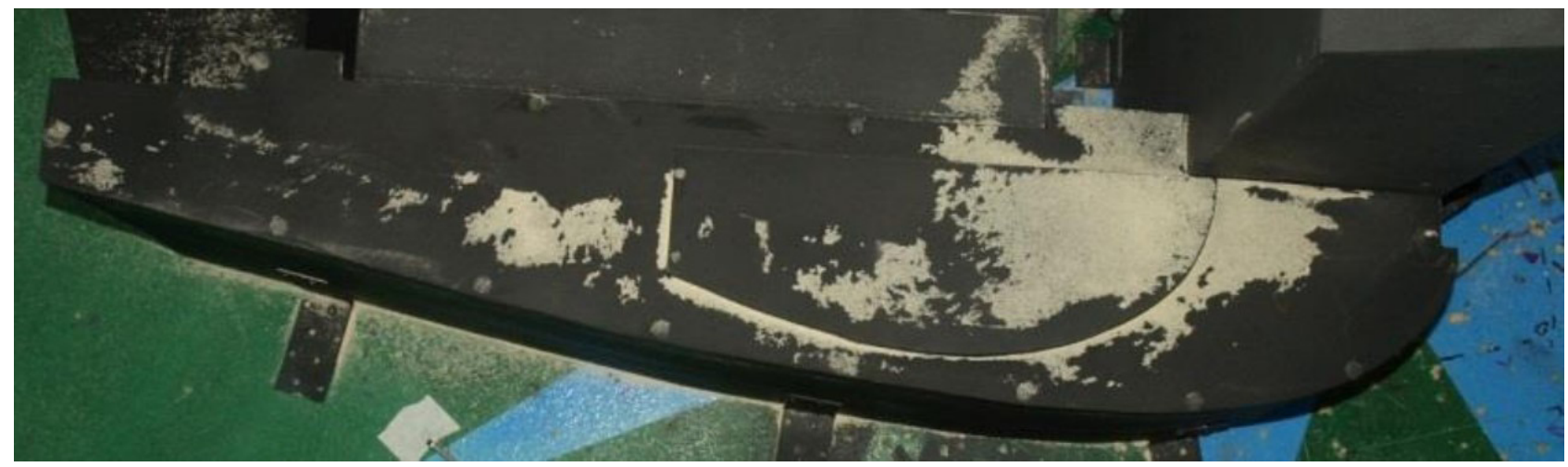

c) Research Institute of Mechanics, Moscow State University

Figure 3. Results of modeling snow loads in WTs 
methods is to simulate snow storms by introducing snow particles or snow substitutes into the flow [44].

2. Methods that measure the nature of wind speeds around a scale model, and snow deposition and snow transport are calculated numerically using field snow data and other climatic information from the nearest weather stations. Snow particles in this approach may or may not be modeled.

Snow accumulation modelling in a water flume is a fairly common approach in foreign practice (e.g. used by the Canadian RWDI). The essence of the method is that a model of a structure is placed under water in a specially designed flume (Fig. 4a). Then water with sand $[6,21,22]$ or crushed walnut shells [23] is passed through the flume. Despite the unphysicality of the obtained distributions (Fig. $4 \mathrm{~b})$, the experiments in the flume are conducted to determine the locations of potential snow bags. Thus, the results obtained are not used as calculation schemes of snow loads, but are of an auxiliary nature. Note that recommendations for assigning snow loads to the Otkritie Arena roof were developed by RDWI using the described method [35].

Due to the small number of climatic WTs, in most cases researchers have resorted to using snow-like materials in conventional WTs. In the absence of the technical feasibility of introducing snow substitutes into the flow, an even more simplified approach is used, where the material is only poured on the model, and a snowless hurricane condition is actually investigated. Obviously, winter storms without significant snowfall are very rare and do not lead to the largest snow loads. Therefore, the use of such a maximally simplified approach can only be justified by the technical unfitness of WT, rather than by the substantiated features of the scientific approach.

\section{PARTICLE METHODS AND SNOW SUBSTITUTES}

Many kinds of snow substitutes can be used with particle methods: sodium tetroborate [24,
25], rice bran [15], sawdust (Fig. 3) [27, 28, 58, 59], clay [4], foam balls [29, 34] (Fig. 5), quartz sand (Fig. 6) [30], baking soda [31], glass beads [10].

Due to a great variety of such materials, studies have been repeatedly carried out to compare them. For example, in [26] wood ash, styrofoam and silica sand are compared under otherwise equal conditions in WT. The comparison indicates that the quartz sand matches the field data better. However, the studies were only carried out on a simple two-level roof geometry

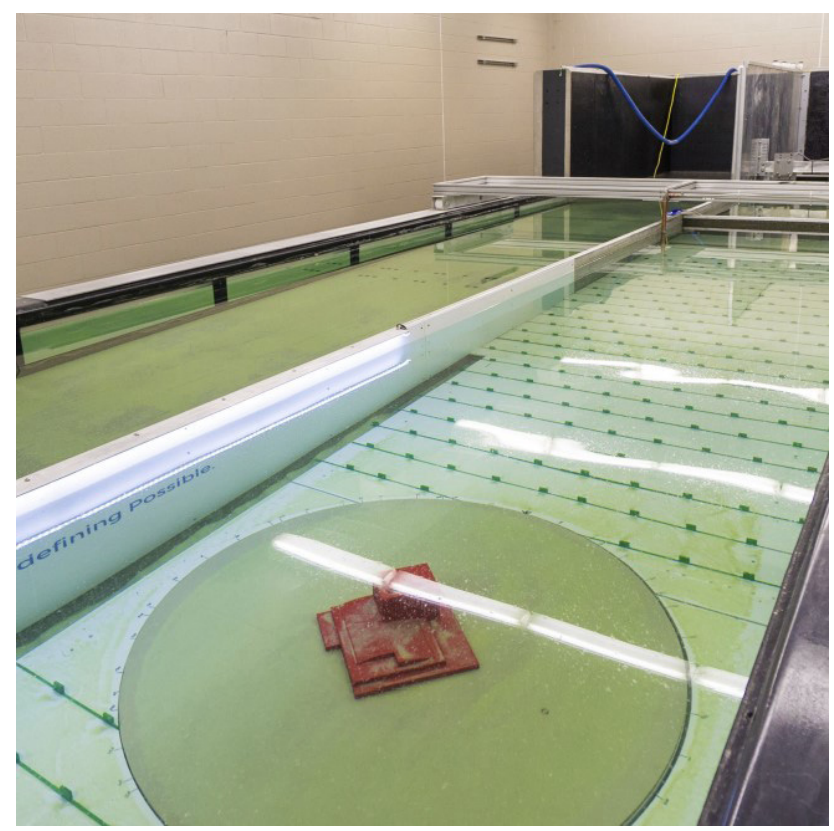

a) before draining the water

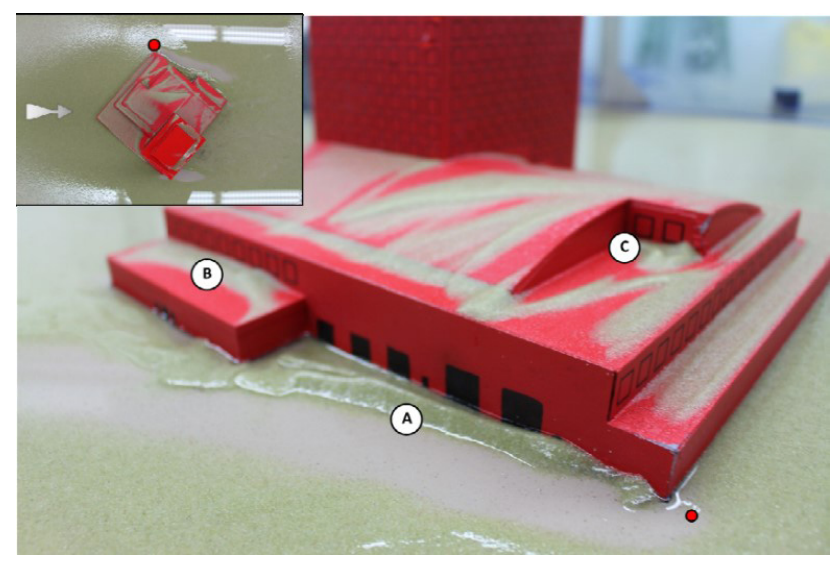

b) after draining the water

Figure 4. Results of an experiment in a water flume [22] 


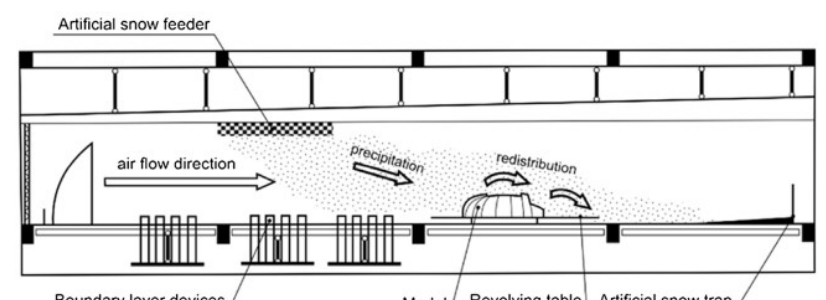

Boundary layer devices Model Revolving table Artificial snow trap

a) the experimental setup

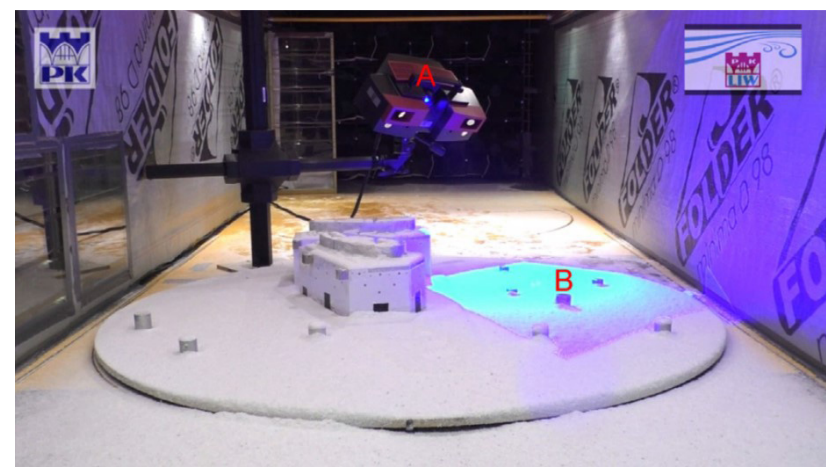

b) the process of $3 D$ scanning of the experimental results

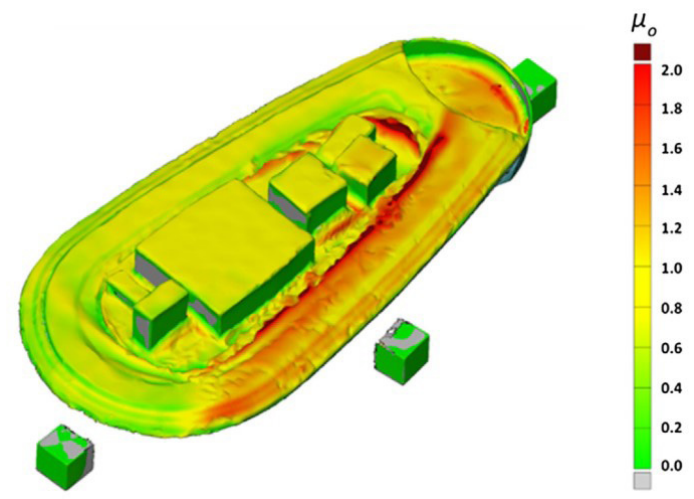

c) shape coefficient $\mu$ (snow hurricane simulation)

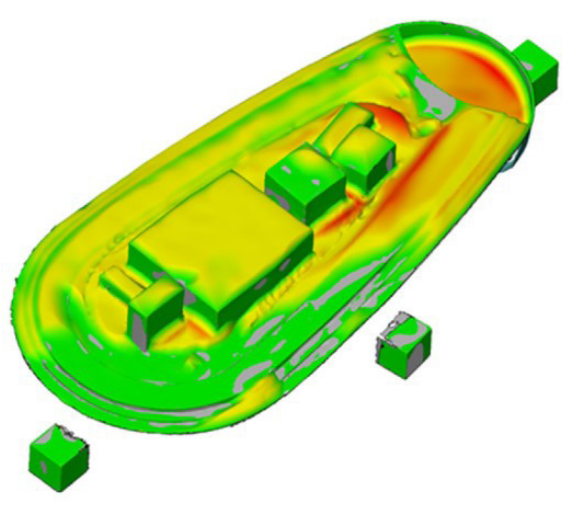

d) shape factor $\mu$

Figure 5. Physical modeling using foam as a snow simulator [34] and the measurements are provided only for the lower level, whereas practice shows that it is on the upper levels that full drift of snow-like material is observed, which is not consistent with the physical considerations and the field data.

According to the ASCE standards [20], the results obtained by the particle methods in assigning snow loads are of an exclusively qualitative nature and should be used in conjunction with regulatory schemes for simple structures, field and climatic data of the construction site. Unfortunately, recommendations on assignment of snow loads, developed by domestic organizations on the basis of blowing in WT, completely lack a comprehensive approach. In fact, schemes of snow loads are given only on the basis of digitization of obtained snow distribution patterns (Fig. 7).

One of the disadvantages of the particle method is the inability to account for snow accumulation over a long period of time (weeks and months) from different wind directions and wind speeds, temperature and humidity conditions. In order to take these factors into account, the ASCE standards [20] recommend using the

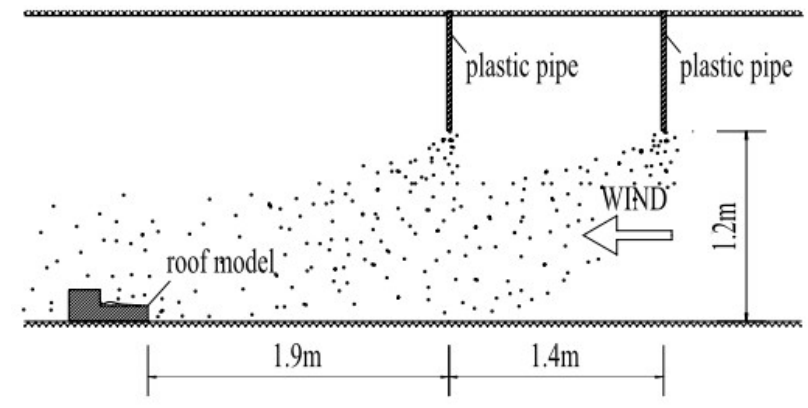

a) the experimental setup
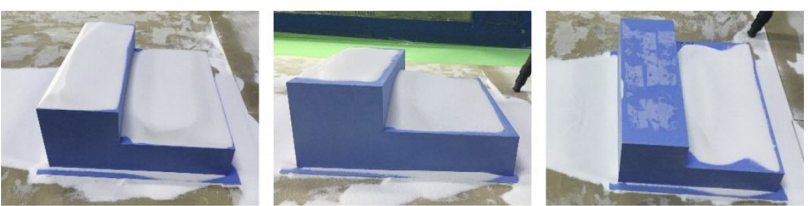

b) results at different wind speeds (from left to right, the wind velocity increases)

Figure 6. Physical modeling using silica sand as a snow-like material [30] 
second category of methods [33], which is numerical modelling based on the results of blowing in WT. At that, it is proposed to first use blowing data without snow substitutes (time step method A), determine the most dangerous angles (taking into account data from the nearest weather stations) and then conduct experiments with substitutes for the corresponding angles (time step method B). In both time step methods, all experimental data obtained together with meteorological data are used only as input parameters for numerical modelling of snow loads during the whole winter period.

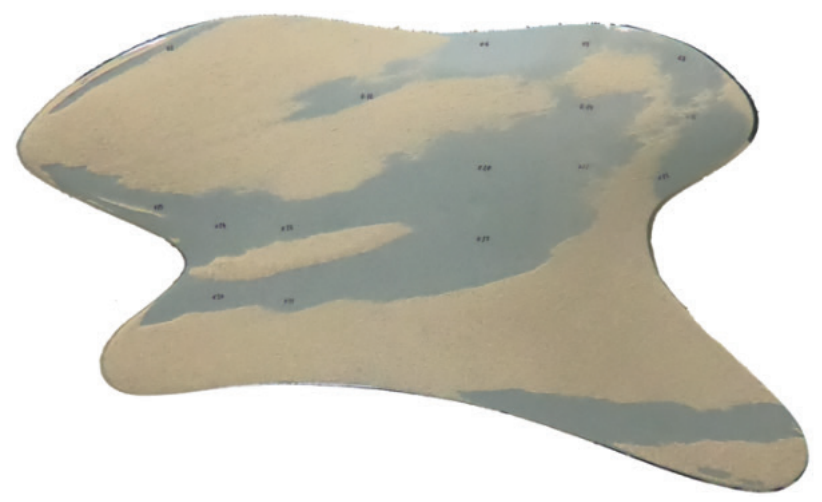

a) distribution of the snow simulator after blowing

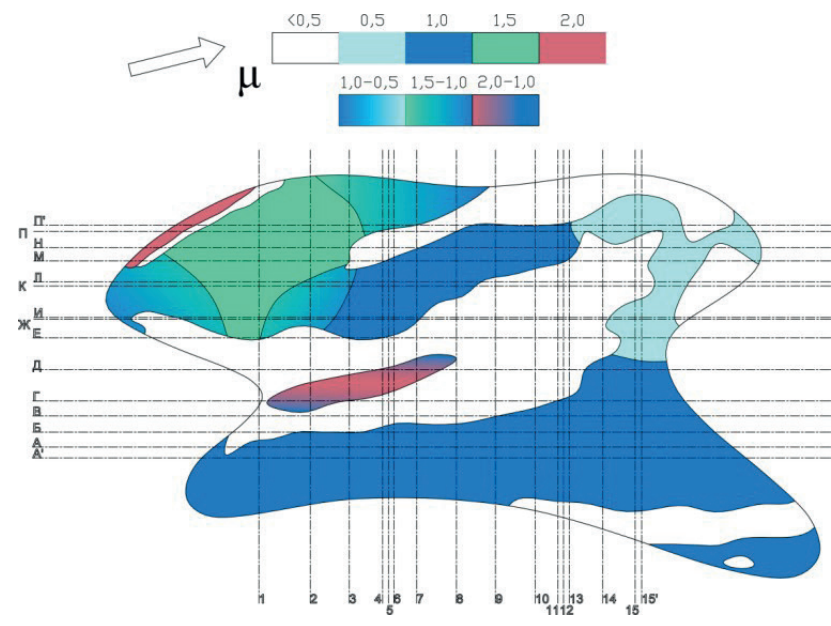

b) recommendations for the appointment of the shape factor $\mu$

Fig. 7 An example of the interpretation of the results of physical modeling "Krylov State Scientific Center"

\section{SIMILARITY CONDITIONS}

It is not possible to achieve complete simulations of snow transport and snow accumulation through scaled-down experiments in WTs or water flumes. Nevertheless, the ASCE standards [20], based on a number of scientific papers [7, $12,32,36]$, put forward several requirements for similarity parameters. Firstly, the following expressions must coincide in the scaled model and the full model:

$$
\frac{w_{t}}{U}, \frac{U^{2}}{\operatorname{Lg} \beta},
$$

where $w_{t}$ is limiting velocity of falling particles, $U$ is average velocity at a characteristic point, $L$ is characteristic building size, $g$ is acceleration due to gravity, $\beta=(\gamma-1)\left(\gamma+\gamma_{a}\right)$ is ratio of particle density to air or liquid density, $\gamma_{a}$ is additional contribution to $\gamma$, due to the coupled mass effect. For air, $\gamma_{a} \approx 0, \beta \approx 1$ (air density is low), for water used in flumes, $\gamma_{a} \approx 0.5$, and for sand, $\beta \approx 0.5$.

The first parameter means that the ratio of particle velocity to flow velocity is the same as in full scale. The second parameter is the densimetric Froude number, the equality of this parameter in real and model ensures that the ratio of aerodynamic force to gravitational force is correct. Satisfying these two parameters can be enough for problems where the interaction of snow particles with surfaces and with each other is not important (for example, the initial deposition of falling snow under the action of the wind or tracking of particles falling from a higher surface to a lower one).

Other parameters must also be observed to correctly account for particle interactions, though. For example, to simulate saltation, the interaction of snow particles with the snow surface must be properly accounted for. An important 
parameter then is the ratio of the average flow velocity $U$ to the threshold velocity of the onset of transport $U_{t h}$ :

$$
\frac{U}{U_{t h}}
$$

An additional requirement is imposed on the mass flux dependence for the model. The model flux must have a dependence similar to the fullscale flux. The flux can be expressed in the following dimensionless form:

$$
\frac{q}{\rho_{p} h_{s} U_{t h}}=c f\left(\frac{U}{U_{t h}}\right),
$$

where $\rho_{p}$ is particle density, $h_{s}$ is the height at which $U$ is defined in (3), $c$ is dimensionless constant (can be different in model and full scale), $h_{s}=0.5-1 \mathrm{~m}$ usually (should be much smaller than the size of the building). The function $f$ must be identical for the model and full scale.

It is shown in [32] that if the ratio (2) is neither too large nor too small, satisfying it has little effect on the experimental result. However, a note is made that this may not be the case for all model geometries. If we discard condition (2), then condition (3) is also not necessary.

Expression (3) can be used to determine the dimensionless time [36]:

$$
\bar{t}=\frac{c U_{t h} h_{s}}{L^{2}} t,
$$

where $t$ is dimensionless time, which has the same value in scale and full-scale models. The model time and full-scale time can be found from the following expression:

$$
\frac{t_{p}}{t_{m}}=\frac{\left(c U_{t h} h_{s}\right)_{m}}{\left(c U_{t h} h_{s}\right)_{p}}=\left(\frac{L_{p}}{L_{m}}\right)^{2},
$$

where the indices $p$ and $m$ denote the full-scale model (prototype) and scaled-down model, respectively. Thus, the time of the experiment depends on the square of the characteristic size of the model $L_{m}{ }^{2}$.

It is shown in [12] that the following conditions must be satisfied:

$$
\begin{gathered}
\frac{u_{* t h}^{3}}{2 g v} \geq 30, \\
\gamma \geq 600,
\end{gathered}
$$

where $u^{*} t h$ is threshold surface shear stress rate for saltating snow, $v$ is kinematic viscosity. Inequality (6) imposes a requirement for minimum Reynolds numbers and inequality (7) imposes a requirement for minimum density ratio. For water flumes, inequality (7) is not fulfilled.

Condition (1) is easily satisfied in WTs, but then it proves impossible to satisfy conditions (2), (6) and (7), which have an impact on saltation. To meet (1), the flow velocity is too low to initiate saltation. Usually, for WTs the requirements for densimetric Froude number are relaxed and instead relations (2), (6) and (7) are satisfied. Failing to satisfy the densimetric Froude number results in exaggerated length and height of the trajectories of the saltating particles.

In water flumes it is possible to satisfy conditions (1), (2) and (6), but due to high water density it is not possible to satisfy condition (7). This also affects physicality of modelling, for dunes and ripples can form on smooth surfaces.

Due to the problems with satisfying the similarity conditions, in the ASCE standards [20] it is recommended to place a reference model (e.g. a two-level roof) next to the model under study, for which the normative distributions of snow load are known. The quality of the experiments performed is then assessed by the degree of consistency with the reference model. The reference model is also used to determine the abso- 
lute value of the shape coefficient $\mu$ on the investigated roof.

\section{PHYSICAL MODELLING AS A MEANS FOR DEVELOPING ADEQUATE MATH- EMATICAL MODELS}

The development of methods of numerical modelling of snow transport and snow accumulation is impossible without previous extensive experimental work. Field and large-scale experiments in climatic WTs are necessary to identify dependencies, determine empirical parameters and verify the developed mathematical models and the algorithms implementing them.

Most of the current numerical approaches to modeling snow transport and snow deposition are based on the development of the so-called CFD methods. To verify the CFD-based methods being developed, it is necessary to experimentally investigate not only the motion of snow masses in the air flow, but also the effect of particles in saltation and suspension on the air flow. Experimental studies of air-snow flow over surfaces form the basis of existing mathematical approaches to modelling of saltation and suspension [37]. The most significant works in this area are listed below.

The most applied empirical dependencies for snow transport velocity were obtained as early as in the last quarter of the 20th century in the works of American [38] and Canadian scientists [39]. However, the universality of the results obtained in these works has never been proven.

Takeuchi [40] carried out field measurements using a snow trap to study the longitudinal distribution of the total snow transport rate, including saltation and suspension. Tabler [41] determined the dependence of seasonal snow transport on the movement of the precipitation zone in the design of fences. Both studies report that the overall snow transport rate reaches an equilibrium state only over areas of a few hundred meters.

In CFD modelling, surface roughness parameters affecting the wind profile and turbulence characteristics near models are important. In mathematical modelling of snow transport this issue is equally important. Significant studies of snow roughness have been conducted on the basis of data from Antarctica obtained by the SANAE IV expedition [42] and participants of the ALW program [43].

\section{MEASUREMENT TECHNIQUES}

This section addresses the measurements used in field observations and large-scale experiments to investigate snow transport and snow accumulation. An overview of measurement methods is not the purpose of this work, so the information given is far from complete. However, knowledge of current technical measurement capabilities gives a better understanding of what can and should be done for snow load research, which is especially relevant in our country. The review does not cover the measurement methods traditionally used in wind load and flow studies.

The known problems of field experiments are high financial cost, long periods of times and substantial labour costs. However, even without specially designed field experiments, simple field measurements of snow cover in winter on roofs of buildings and structures can be of great benefit. The creation of a special database containing snow distributions on different roofs, indicating the year, geographical location and available climatic and meteorological data will be invaluable for developing physical and mathematical modelling, improving the regulatory framework and will be a visual reference for practicing calculation engineers to form an intuitive understanding of snow mechanics. Special atlases [45-47] serve as analogues of such databases in aerodynamics, alt- 
hough they are largely outdated now. Increasingly popular machine learning methods require large data sets for their implementation to train neural networks. Such a database could provide suitable material for training.

With the use of drones, modern cameras and special software (all of which are now available at a ridiculously low prices by the standards of modern science), collecting a database of snow distribution on roofs of any shape is not an insurmountable task. Existing photo-processing methods provide three-dimensional pictures of snow distribution with an accuracy that exceeds the practical needs of construction [48]. This digital approach does not require measuring levels or other sensors to be installed on the roofs of buildings $[18,54]$, which usually presents considerable organizational and technical difficulties.

The results of experiments in WTs or water flumes can be handled in a similar way [49], although a more accurate and technologically advanced method would be to use a dedicated 3D scanner [34]. Previously, achieving snow distribution contours was done in a very simple way, which is by tracing the level on a cardboard submerged in snow or snow-like material [18]. Such a method allows to easily obtain snow distribution in the selected sections, but its main disadvantage is that the snow cap deteriorates with each measurement made.

Snow particle counters [50] for measuring point snow fluxes or high-speed cameras with subsequent software processing for measuring snow fluxes in the area are widely used in the world practice to investigate the processes of saltation and suspension.

\section{RECOMMENDATIONS FOR UPGRAD- ING DOMESTIC WTS AND IMPROVING PHYSICAL MODELLING TECHNIQUES}

The above materials clearly show the underdevelopment of the technical equipment of domes- tic WTs and the low level of the methodology used in developing recommendations for assigning snow loads to roofs with arbitrary geometry. These problems create risks when estimating mechanical safety of modern structures, including long-span structures, for which snow loads make the main contribution.

The following minimum recommendations can be given to remedy this situation:

1. It is necessary to modernize WTs in accordance with international experience:

1.1 Equip WTs with a snow substitute feeding system to simulate snow storms, rather than the rare snowless hurricanes that hardly ever occur in winter. Such systems come in a variety of forms depending on the WT characteristics, but in all cases, verification of the system with simple normative examples is required.

1.2. Equip WTs with the necessary measuring equipment to digitize the resulting snow substitute distribution patterns.

2. On the basis of international experience and in accordance with foreign regulatory documents, develop and verify a methodology for simulating snow loads on roofs with arbitrary geometry:

2.1. Different wind directions and velocities, snow accumulation over a long period of time (weeks and months) under different temperature and humidity regimes must be taken into account. The results of simulations of single snowstorms in the WT should be the input data for such a methodology, not its output.

2.2. The reference snow layer thickness should be determined either by blowing into an empty (without a model) WT or by comparison with a reference model placed next to the test one.

3. Develop regulatory documents [62] establishing requirements for testing in WTs in terms of snow load simulation: similarity conditions, preferred snow substitutes, characteristics of snow substitute feeding systems, measurement methods, etc. 


\section{CONCLUSIONS}

1. A review of the development and current state of the methods of physical modeling of snow transport and snow accumulation has been conducted according to scientific publications and regulatory documents. A critical analysis of Russian publications and contractual works on the subject of the article is carried out.

2. The review has shown that the experimental works carried out in Russia for the purpose of determining the shape coefficient $\mu$ are methodologically at a dismally low level, even in comparison with foreign works of half a century ago:

2.1. Russian WTs do not actually simulate individual snow storms or snowfalls, but rather simulate the removal of a uniform layer of snow from roof during strong winds. This primitive approach has not been used in any foreign laboratory recognized by the world scientific and regulatory community for a long time.

2.2. The reason for the widespread choice of wood flour as a snow-like material is unclear, especially since a number of studies show that silica sand matches the field data best.

2.3. The choice of the reference value of snow cover thickness necessary to calculate the shape coefficient $\mu$ is arbitrary and is not based on anything. The reference snow thickness can be determined by the thickness of the snow substitute cover away from the model (or by blowing without the model) when simulating snowfall, or by comparison with a reference standard model of a simple shape, which is located next to the model under study. Neither of these approaches is used in Russian laboratories.

2.4. Recommendations for assigning the shape coefficient $\mu$ are "manufactured" from the results of elementary digitization of pictures of the remaining snow cover. Note that these pictures clearly contradict the physical meaning. This approach also directly contradicts foreign standards, where it is clearly stated that the resulting patterns are used as additional data for subsequent analysis and modelling.

2.5. Modelling in WTs or water flumes can reproduce the conditions of a snow storm or just snowfall. Thoughtless use of the results of these experiments for developing recommendations leads to the fact that snow distributions formed throughout the entire cold season by many snowfalls, different wind directions, thermal and moisture regimes are not taken into account at all.

2.6. The current practice in Russian laboratories casts serious doubt on the legitimacy of the recommendations being developed and poses significant risks to the mechanical safety of unique large-span buildings and structures.

3. The Russian Building Code SP 20.13330.2016 [61] prescribes that for buildings and structures with overall dimensions in plan exceeding $100 \mathrm{~m}$, as well as in cases not stipulated in Annex B, model tests in WTs to determine the shape coefficient $\mu$ must be carried out. For some reason, it is not allowed to conduct tests in water flumes, which is an absolutely equal and recognized approach (both in regulatory documents and scientific publications) all over the developed world on a par with WTs.

4. Simultaneous satisfaction of all similarity conditions for modelling of snow transport and snow accumulation processes is impossible neither in WTs, nor in water flumes. Therefore, even the model tests carried out at the highest level never fully reproduce the real full-scale effects of creep, saltation and suspension. This situation, coupled with the continuous improvement of mathematical models, numerical methods, computer technologies and related software, makes the development and future implementation of numerical modelling in real construction practice and regulatory documents inevitable.

5. The best results of physical modelling of shape coefficient $\mu$ are obtained in large-scale tests in climatic WTs. Normative distributions 
are easily guessed in these results for simple roof shapes. Climatic tests are rather complicated and costly (also in terms of time) for their direct application in the industrial sector, but they can be a powerful tool for the development of SP 20 in terms of introducing snow load schemes for more complex roof shapes.

6. Improvement of the regulatory framework, development of methods of both physical and mathematical modelling, is extremely difficult without full-scale experiments or measurements as well as large-scale tests in climatic WTs. Taking into account the lack of climatic WTs in Russia and the difficulties in organizing fullscale experiments, it is proposed to make fullscale measurements by means of drone photography and subsequent processing of the results. Such a low-cost method will make it possible to create a base containing snow distribution on different roofs with indication of year, geographical location and available climatic and meteorological data, which will give an impetus for development of physical and mathematical modeling, improvement of normative base and will be a visual reference for practicing engineers.

7. Recommendations on modernization of domestic WTs, improvement of methodologies and standard-setting to correct the current dangerous practice of domestic laboratories developing scientifically unfounded recommendations on assigning snow loads to roofs with arbitrary geometry are proposed.

\section{ACKNOWLEDGMENTS}

This work was financially supported by the Ministry of Science and Higher Education of the Russian Federation (Project: Theoretical and experimental design of new composite materials to ensure safety during the operation of buildings and structures under conditions of technogenic and biogenic threats \#FSWG-2020-0007)

\section{REFERENCES}

1. Finney, E. A. (1934). Snow control on the high-ways. Michigan Engineering Experiment Station Bulletin, 57, 1-62.

2. Anno, Y. (1984). Requirements for modeling of a snowdrift. Cold regions science and technology, 8(3), 241-252.

3. Anno, Y. (1985). Froude number paradoxes in the modeling of a snowdrift. Cold Regions Science and Technology, 10(2), 191-192.

4. Anno, Y. (1985). Modelling a snowdrift by means of activated clay particles. Annals of Glaciology, 6, 48-52.

5. Irwin, P. A., \& Williams, C. J. (1981). Prevention of excess snow accumulation due to roof mounted solar collectors. Rept. for Ministry of Municipal Affairs and Housing of Ontario.

6. Irwin, P. A. (1983). Application of snow simulation model tests to pianning and design. In Proc. Eastern Snow Conference, Vol. 28, 40th annual Meeting (Vol. 28, pp. 118-130).

7. Irwin, P. A., Hochstenbach, F. M., Gam-ble, S. L., \& Davies, R. W. (2000). Wind and snow considerations for wide span enclosures. In Widespan Roof Structures (pp. 62-72). Thomas Telford Publishing.

8. Irwin, P.A. (2020). Lifetime experiences in wind engineering. Journal of Wind Engineering and Industrial Aerodynamics, 205, 104272.

9. Iversen, J. D. (1979). Drifting snow similitude. Journal of the hydraulics division, 105(6), 737-753.

10. Iversen, J. D. (1980). Drifting-snow similitude-transportrate and roughness modeling. Journal of glaciology, 26(94), 393-403.

11. Kind, R. J., \& Murray, S. B. (1982). Saltation flow measurements relating to modeling of snowdrifting. Journal of Wind Engineering and Industrial Aerodynamics, 10(1), 89-102.

12. Kind, R. J. (1986). Snowdrifting: a review of modelling methods. Cold Regions Science and Technology, 12(3), 217-228. 
13. Odar, F. (1962). Scale factors for simulation of drifting snow. Journal of the Engineering Mechanics Division, 88(2), 1-16.

14. Odar, F. (1965). Simulation of drifting snow. U.S. Cold Regions Research and Engineering Laboratory. Research Report 174

15. Isyumov, N., \& Mikitiuk, M. (1990). Wind tunnel model tests of snow drifting on a twolevel flat roof. Journal of Wind Engineering and Industrial Aerodynamics, 36, 893-904.

16. Isyumov, N., \& Mikitiuk, M. (1992). Wind tunnel modeling of snow accumulations on large-area roofs. In Proc., 2nd Int. Conf. On Snow Engineering (pp. 181-193).

17. Sanpaolesi, L., Currie, D., Sims, P., Sacré, C., Stiefel, U., Lozza, S., ... \& Formichi, P. (1998). Scientific support activity in the field of structural stability of civil engineering works: Snow loads. Final report phase I. Report, Commission of the European Communities. DGIII-D3, 2.Sanpaolesi L. et al. Scientific support activity in the field of structural stability of civil engineering works: Snow loads //Final Report Phase II. Brussels: Commission of the European Communities. DGIII-D3. - 1998.

18. Standard B. Eurocode 1: Actions on structures. -2010 .

19. ASCE. Wind Tunnel testing for buildings and other structures. - American Society of Civil Engineers, 2012.

20. C.J. Williams (1986). Field Observations of Wind Deflection Fins to Control Snow Accumulations on Roofs // Proc. 1st Int. Conf. on Snow Eng. (pp. 307-314).

21. Brooks, A., Dale, J., Gamble, S., \& Kriksic, F. (2015). Rapid Assessment of Snow Drifting Conditions Using Physical Model Simulations. In Cold Regions Engineering 2015 (pp. 310-321).

22. O'Rourke, M., DeGaetano, A., \& Tokarczyk, J. D. (2004). Snow drifting transport rates from water flume simulation. Journal of wind engineering and industrial aerodynamics, 92(14-15), 1245-1264.

23. Gerdel, R. W., \& Strom, G. H. (1961). Wind tunnel studies with scale model simulated snow. International Association of Scientific Hydrology.

24. Younger, A. (2017). Simulate and test different tent arrangements in windy and snowy conditions.

25. Zhou, X., Hu, J., \& Gu, M. (2014). Wind tunnel test of snow loads on a stepped flat roof using different granular materials. Natural Hazards, 74(3), 1629-1648.

26. Naaim, M., Naaim-Bouvet, F., \& Mar-tinez, H. (1998). Numerical simulation of drift-ing snow: erosion and deposition models. An-nals of glaciology, 26, 191-196.

27. Zhou, X., Qiang, S., Peng, Y., \& Gu, M. (2016). Wind tunnel test on responses of a lightweight roof structure under joint action of wind and snow loads. Cold Regions Science and Technology, 132, 19-32.

28. Kumar, G., Gairola, A., \& Vaid, A. (2020). Flow and deposition measurement of foam beads in a closed recirculating wind tunnel for snowdrift modelling. Flow Measurement and Instrumentation, 72, 101687.

29. Wang, J., Liu, H., Chen, Z., \& Ma, K. (2020). Wind tunnel test of wind-induced snowdrift on stepped flat roofs during snowfall. Natural Hazards, 104(1), 731-752.

30. Smedley, D. J., Kwok, K. C. S., \& Kim, D. H. (1993). Snowdrifting simulation around Davis station workshop, Antarctica. Journal of Wind Engineering and Industrial Aerodynamics, 50, 153-162.

31. Peterka, J. A., \& Petersen, R. L. (1990). On the relaxation of saltation length as a modeling criteria for particulate transport by wind. Journal of Wind Engineering and Industrial Aerodynamics, 36, 867-876.

32. Peterka, J. A., \& Esterday, W. S. (2004). Roof design snow loads by wind tunnel test and analysis. In Structures 2004: Building on the Past, Securing the Future (pp. 1-9).

33. Flaga, A., Bosak, G., Pistol, A., \& Flaga, L. (2019). Wind tunnel model tests of snow precipitation and redistribution on rooftops, terraces and in the vicinity of high-rise buildings. Archives of Civil and Mechanical Engineering, 19(4), 1295-1303. 
34. Ayres, P., \& Webster, T. (2014). Otkritie Arena: Design of the new Spartak Moscow Stadium. Stahlbau, 83(6), 400-405.

35. Iversen, J. D. (1982). Small-scale Modeling of Snow-drift Phenomena, Wind Tunnel Modeling for Civil Engineerin $\sim$ ADolications. Cambridge University Press, Cambridge, England, 522-545.

36. Okaze, T., Mochida, A., Tominaga, Y., Nemoto, M., Sato, T., Sasaki, Y., \& Ichinohe, K. (2012). Wind tunnel investigation of drifting snow development in a boundary layer. Journal of wind engineering and industrial aerodynamics, 104, 532-539.

37. Iversen, J. D., Greeley, R., White, B. R., \& Pollack, J. B. (1975). Eolian erosion of the Martian surface, part 1: Erosion rate similitude. Icarus, 26(3), 321-331.

38. Pomeroy, J. W., \& Gray, D. M. (1990). Saltation of snow. Water resources research, 26(7), 1583-1594.

39. Takeuchi, M. (1980). Vertical profile and horizontal increase of drift-snow transport. Journal of Glaciology, 26(94), 481-492.

40. Tabler, R. D. (2003). Controlling blowing and drifting snow with snow fences and road design (No. NCHRP Project 20-7 (147)).

41. Beyers, J. H. M., \& Harms, T. M. (2003). Outdoors modelling of snowdrift at SANAE IV Research Station, Antarctica. Journal of Wind Engineering and Industrial Aerodynamics, 91(4), 551-569.

42. Bintanja, R. (2001). Modification of the wind speed profile caused by snowdrift: results from observations. Quarterly Journal of the Royal Meteorological Society, 127(577), 2417-2434.

43. Brooks, A., Gamble, S., Dale, J., \& Bond, J. (2016). Comparison of Physical Snow Accumulation Simulation Techniques. In Proceedings of the International Conference on Snow Engineering (ICSE 2016), Nantes, France.

44. Ван-Дайк, М. (1986). Альбом течений жидкости и газа [An Album of Fluid Motion]. М.: Мир.
45. Ушаков, Б.А. (2013). Атлас аэродинамических характеристик профилей крыльев, испытанных в трубе Т-1 [Atlas of aerodynamic characteristics of wing profiles tested in a tube T-1]. Рипол Классик.

46. Березин М.А., Катюшин В.В. Атлас аэродинамических характеристик строительных конструкций [Atlas of aerodynamic characteristics of building structures]. -2003.

47. Chiba T., Thiis T. (2016). Accuracy of snow depth measurements on roofs measured with photogrammetry. In Proceedings of the International Conference on Snow Engineering (ICSE 2016), Nantes, France.

48. Yan, K., \& Cheng, T. (2008, August). Close Shot Photogrammetry for Measuring WindDrifted Snow Distribution on Stepped Flat Roofs. In 2008 ISECS International Colloquium on Computing, Communication, Control, and Management (Vol. 1, pp. 332-335). IEEE.

49. Sato, T., Kimura, T., Ishimaru, T., \& Maruyama, T. (1993). Field test of a new snow-particle counter (SPC) system. Annals of Glaciology, 18, 149-154.

50. Nazarov YU. P., Lebedeva I. V., Popov N. A. Regional'noye normirovaniye snegovykh nagruzok $v$ Rossii [Regional rationing of snow loads in Russia]//Stroitel'naya mekhanika i raschet sooruzheniy. - 2006. - No 3. - P. 71-77.

51. Ledovskoy I. V. Problemy teorii snegovykh nagruzok na sooruzheniya [Problems of the theory of snow loads on structures] //Avtoreferat. P. -2009.

52. Vinnik N. S., Matyukh S.A., Morozova, V.A. Raspredeleniye snegovoy nagruzki na pokrytiyakh zdaniy i sooruzheniy i faktory, na neye vliyayushchiye [Distribution of snow load on the coatings of buildings and structures and factors affecting it]. -2015 .

53. Lobkina V. A., Kononov I. A., Potapov A. A. Sistema distantsionnogo monitoringa snegovoy nagruzki na krovle zdaniy [System for remote monitoring of snow load on the roof of buildings] //Lyod i Sneg. - 2016. - Vol. 56. - No. 2. - P. 246-252. 
54. Adzhiyev A. KH. i dr. Issledovaniya raschetnykh znacheniy vesa snegovogo pokrova i znacheniy vysotnogo koeffitsiyenta $\mathrm{v}$ gornykh i maloizuchennykh rayonakh dlya opredeleniya nagruzok na zdaniya i sooruzheniya [Studies of the calculated values of the weight of the snow cover and the values of the altitude coefficient in mountainous and poorly studied areas to determine the loads on buildings and structures] //Prirodnyye i tekhnogennyye riski. Bezopasnost' sooruzheniy. -2021 . - No. 1. - P. 47-50.

55. Matveyenko, Ye. V. Obobshchennyy analiz metodov modelirovaniya snegovoy nagruzki [Generalized analysis of methods for modeling snow load] / Ye. V. Matveyenko // Vestnik Brestskogo gosudarstvennogo tekhnicheskogo universiteta. Stroitel'stvo i arkhitektura. - 2018. - No 1(109). - P. 77-81.

56. Popov N. A. i dr. Vozdeystviye vetrovykh i snegovykh nagruzok na bol'sheproletnyye pokrytiya [Impact of wind and snow loads on large-span pavements] //Promyshlennoye i grazhdanskoye stroitel'stvo. - 2016. - No 12. - P. 71-76

57. Poddaeva O. Experimental modeling of snow action on unique construction facilities // Architecture and Engineering. - 2021. - Vol. 6. - No. 2. - P. 45-51.

58. Poddaeva O., Churin P. Experimental study of the distribution of snow deposits on the surface of structures with complex threedimensional shape of the roof//Proceedings of the International Conference on Snow Engineering (ICSE 2016), Nantes, France. - 2016.

59. Tominaga, Y., Okaze, T., Mochida, A., Sasaki, Y., Nemoto, M., \& Sato, T. (2013). PIV measurements of saltating snow particle velocity in a boundary layer developed in a wind tunnel. Journal of visualization, 16(2), 95-98.

60. Belostotsky, A.M., Britikov, N.A., Goryachevsky, O.S. (2021). Comparison of determination of snow loads for roofs in building codes of various countries. International Journal for Computational Civil and Structural Engineering, 17(3), 39-47.

\section{СПИСОК ЛИТЕРАТУРЫ}

1. Finney E. A. Snow control on the high-ways //Michigan Enginnering Experiment Station Bulletin. - 1934. - T. 57. - C. 1-62.

2. Anno Y. Requirements for modeling of a snowdrift //Cold regions science and technology. - 1984. - T. 8. - №. 3. - C. 241-252.

3. Anno Y.Froude number paradoxes in the modeling of a snowdrift //Cold Regions Science and Technology. - 1985. - T. 10. - №. 2. - C. 191-192.

4. Anno Y. Modelling a snowdrift by means of activated clay particles //Annals of Glaciology. - 1985. - T. 6. - C. 48-52.

5. Irwin P. A., Williams C. J. Prevention of excess snow accumulation due to roof mounted solar collectors //Rept. for Ministry of Municipal Affairs and Housing of Ontario. - 1981.

6. Irwin P. A. Application of snow simulation model tests to planning and design //Proc. Eastern Snow Conference, Vol. 28, 40th annual Meeting. - 1983. - T. 28. - C. 118-130.

7. Irwin P. A., Hochstenbach F. M., Gamble S. L. Wind and snow considerations for wide span enclosures//Widespan Roof Structures. $-2000 .-$ C. 62.

8. Irwin P. A. Lifetime experiences in wind engineering //Journal of Wind Engineering and Industrial Aerodynamics. - 2020. - T. 205. - C. 104272.

9. Iversen J. D. Drifting snow similitude //Journal of the hydraulics division. -1979 . $-\mathrm{T}$. 105. - №. 6. - C. 737-753.

10. Iversen J. D. Drifting-snow similitude-transport-rate and roughness modeling //Journal of glaciology. - 1980. - T. 26. - №. 94. - C. 393-403.

11. Kind R. J., Murray S. B. Saltation flow measurements relating to modeling of snowdrifting //Journal of Wind Engineering and Industrial Aerodynamics. - 1982. - T. 10. - №. 1. - C. 89-102.

12. Kind R. J. Snowdrifting: a review of modelling methods // Cold Regions Science and Technology. - 1986. - T. 12. - №. 3. - C. 217-228. 
13. Odar F. Scale factors for simulation of drifting snow //Journal of the Engineering Mechanics Division. - 1962. - T. 88. - №. 2. - C. 1-16.

14. Odar F. Simulation of Drifting Snow, Cold Regions Research and Engineering Laboratory, Hanover. - NH, Research Report 174, 1965.

15. Isyumov N., Mikitiuk M. Wind tunnel model tests of snow drifting on a two-level flat roof //Journal of Wind Engineering and Industrial Aerodynamics. - 1990. - T. 36. - C. 893-904.

16. Isyumov N., Mikitiuk M. Wind tunnel modeling of snow accumulations on large-area roofs //Proc., 2nd Int. Conf. On Snow Engineering. - 1992. - C. 181-193.

17. Sanpaolesi L. et al. Scientific support activity in the field of structural stability of civil engineering works: Snow loads //Final Report Phase I. Brussels: Commission of the European Communities. DGIII-D3. - 1998.

18. Sanpaolesi L. et al. Scientific support activity in the field of structural stability of civil engineering works: Snow loads //Final Report Phase II. Brussels: Commission of the European Communities. DGIII-D3. - 1998.

19. Standard B. Eurocode 1: Actions on structures. -2010 .

20. ASCE. Wind tunnel testing for buildings and other structures. - American Society of Civil Engineers, 2012.

21. C.J. Williams. Field Observations of Wind Deflection Fins to Control Snow Accumulations on Roofs // Proc. 1st Int. Conf. on Snow Eng. - 1986. - C. 307-314.

22. Brooks A. et al. Rapid Assessment of Snow Drifting Conditions Using Physical Model Simulations //Cold Regions Engineering 2015. - 2015. - C. 310-321.

23. M. O'Rourke, A. DeGaetano, J.D. Tokarczyk. Snow Drifting Transport Rates from Water Flume Simulation. Journal of Wind Engineering and Industrial Aerodynamics. 92, (2004) 1245-1264. Gerdel

24. R. W., Strom G. H. Wind tunnel studies with scale model simulated snow. - Interna-tional Association of Scientific Hydrology, 1961.
25. Younger A. Simulate and test different tent arrangements in windy and snowy conditions. $-2017$.

26. Zhou X., Hu J., Gu M. Wind tunnel test of snow loads on a stepped flat roof using different granular materials //Natural hazards. - 2014. - T. 74. - №. 3. - C. 1629-1648

27. Naaim M., Naaim-Bouvet F., Martinez H. Numerical simulation of drifting snow: erosion and deposition models //Annals of glaciology. - 1998. - T. 26. - C. 191-196.

28. Zhou X. et al. Wind tunnel test on responses of a lightweight roof structure under joint action of wind and snow loads //Cold Regions Science and Technology. - 2016. - T. 132. - C. 19-32.

29. Kumar G., Gairola A., Vaid A. Flow and deposition measurement of foam beads in a closed recirculating Wind tunnel for snowdrift modelling //Flow Measurement and Instrumentation. - 2020. - T. 72. - C. 101687.

30. Wang J. et al. Wind tunnel test of wind-induced snowdrift on stepped flat roofs during snowfall //Natural Hazards. - 2020. - T. 104. - №. 1. - C. 731-752.

31. Smedley D. J., Kwok K. C. S., Kim D. H. Snowdrifting simulation around Davis station workshop, Antarctica //Journal of Wind Engineering and Industrial Aerodynamics. - 1993. - T. 50. - C. 153-162.

32. Peterka J. A., Petersen R. L. On the relaxation of saltation length as a modeling criteria for particulate transport by wind //Journal of Wind Engineering and Industrial Aerodynamics. - 1990. - T. 36. - C. 867-876.

33. Peterka J. A., Esterday W. S. Roof design snow loads by Wind tunnel test and analysis //Structures 2004: Building on the Past, Securing the Future. - 2004. - C. 1-9.

34. Flaga A. et al. Wind tunnel model tests of snow precipitation and redistribution on rooftops, terraces and in the vicinity of high-rise buildings //Archives of Civil and Mechanical Engineering. - 2019. - T. 19. - C. 1295-1303.

35. Ayres P., Webster T. Otkritie Arena: Design of the new Spartak Moscow Stadium //Stahlbau. - 2014. - T. 83. - №. 6. - C. 400-405. 
36. Iversen J. D. Small-scale Modeling of Snowdrift Phenomena, Wind Tunnel Modeling for Civil Engineerin ADolications //Cambridge University Press, Cambridge, England. - 1982. - C. 522-545.

37. Okaze T. et al. Wind tunnel investigation of drifting snow development in a boundary layer //Journal of wind engineering and industrial aerodynamics. -2012 . - T. 104. - C. 532-539.

38. Iversen J. D. et al. Eolian erosion of the Martian surface, part 1: Erosion rate similitude // Icarus. - 1975. - T. 26. - №. 3. - C. 321-331.

39. Pomeroy J. W., Gray D. M. Saltation of snow //Water resources research. $-1990 .-\mathrm{T}$. 26. - №. 7. - C. 1583-1594.

40. Takeuchi M. Vertical profile and horizontal increase of drift-snow transport //Journal of Glaciology. - 1980. - T. 26. - №. 94. - C. 481-492.

41. Tabler R. D. Controlling blowing and drifting snow with snow fences and road design. 2003. - №. NCHRP Project 20-7 (147).

42. Beyers J. H. M., Harms T. M. Outdoors modelling of snowdrift at SANAE IV Research Station, Antarctica //Journal of Wind Engineering and Industrial Aerodynamics. - 2003. - T. 91. - №. 4. - C. 551-569.

43. Bintanja R. Modification of the wind speed profile caused by snowdrift: results from observations //Quarterly Journal of the Royal Meteorological Society. - 2001. - T. 127. - №. 577. - C. 2417-2434.

44. Brooks A. et al. Comparison of Physical Snow Accumulation Simulation Techniques //Proceedings of the International Conference on Snow Engineering (ICSE 2016), Nantes, France. - 2016.

45. Ван-Дайк М. Альбом течений жидкости и газа. - М.: Мир, 1986. - 184 с.

46. Ушаков Б.А. Атлас аэродинамических характеристик профилей крыльев, испытанных в трубе Т-1. - Рипол Классик, 2013.

47. Березин М. А., Катюшин В.В. Атлас аэродинамических характеристик строительных конструкций. - 2003.
48. Chiba T., Thiis T. Accuracy of snow depth measurements on roofs measured with photogrammetry //Proceedings of the International Conference on Snow Engineering (ICSE 2016), Nantes, France. - 2016.

49. Yan K., Cheng T. Close Shot Photogrammetry for Measuring Wind-Drifted Snow Distribution on Stepped Flat Roofs //2008 ISECS International Colloquium on Computing, Communication, Control, and Management. - IEEE, 2008. - T. 1. - C. 332-335.

50. Sato T. et al. Field test of a new snow-particle counter (SPC) system //Annals of Glaciology. - 1993. - T. 18. - C. 149-154.

51. Назаров Ю. П., Лебедева И. В., Попов Н. А. Региональное нормирование снеговых нагрузок в России //Строительная механика и расчет сооружений. - 2006. - №. 3. - С. 71-77.

52. Ледовской И. В. Проблемы теории снеговых нагрузок на сооружения // Автореферат. С. - 2009.

53. Винник Н. С., Матюх С.А., Морозова, В.А. Распределение снеговой нагрузки на покрытиях зданий и сооружений и факторы, на нее влияющие. - 2015.

54. Лобкина В. А., Кононов И. А., Потапов А. А. Система дистанционного мониторинга снеговой нагрузки на кровле зданий //Лёд и Снег. - 2016. - Т. 56. - №. 2. - С. 246-252.

55. Аджиев А. Х. и др. Исследования расчетных значений веса снегового покрова и значений высотного коэффициента в горных и малоизученных районах для определения нагрузок на здания и сооружения //Природные и техногенные риски. Безопасность сооружений. -2021. - №. 1. - C. 47-50.

56. Матвеенко, Е. В. Обобщенный анализ методов моделирования снеговой нагрузки /Е. В. Матвеенко // Вестник Брестского государственного технического университета. Строительство и архитектура. - 2018. - № 1(109). - С. 77-81.

57. Попов Н. А. и др. Воздействие ветровых и снеговых нагрузок на большепролетные 
покрытия //Промышленное и гражданское строительство. - 2016. - №. 12. - С. 71-76.

58. Poddaeva O. Experimental modeling of snow action on unique construction facilities //Architecture and Engineering. - 2021. - T. 6. - №. 2. - C. 45-51.

59. Poddaeva O., Churin P. Experimental study of the distribution of snow deposits on the surface of structures with complex three-dimensional shape of the roof//Proceedings of the International Conference on Snow Engineering (ICSE 2016), Nantes, France. - 2016.
60. Tominaga Y. et al. PIV measurements of saltating snow particle velocity in a boundary layer developed in a wind tunnel //Journal of visualization. - 2013. - T. 16. - №. 2. - C. 95-98.

61. Белостоцкий А.М., Бритиков Н.А., Горячевский О.С. Сравнение нормативных документов различных стран в части назначения снеговых нагрузок // International Journal for Computational Civil and Structural Engineering. - 2021. - T. 17. - №. 3. - C. 39-47.
Belostotsky Alexander Mikhailovich, RAACS academician, professor, D.Sc. in Engineering; General Director of Scientific Research Center StaDyO; Professor of the Department of Informatics and Applied Mathematics of the National Research Center, scientific director of the A.B. Zolotov NICCM of the National Research Moscow State University of Civil Engineering; Professor of the Department of Building Structures, Buildings and Structures of the Russian University of Transport (MIIT); 125040, Russia, Moscow, 3rd Yamsky Pole, 18, office 810; Tel.+7 (499) 706-88-10. E-mail: amb@ stadyo.ru

Goryachevsky Oleg Sergeevich, Lead Computing Engineer at Scientific Research Center StaDyO; Deputy Director of the A.B. Zolotov NICCM of the National Research Moscow State University of Civil Engineering; 129337, Russia, Moscow, Yaroslavskoe shosse, 26. E-mail: osgoryachevskij@mail.ru

Britikov Nikita Aleksandrovich, engineer of the A.B. Zolotov NICCM of the National Research Moscow State University of Civil Engineering; postgraduate student of the Russian University of Transport (MIIT); 129337, Russia, Moscow, Yaroslavskoe shosse, 26. E-mail: n.a.britikov@gmail.com
Белостоикий Александр Михайлович, академик РААСН, профессор, доктор технических наук; генеральный директор ЗАО Научно-исследовательский центр СтаДиО; профессор кафедрыИнформатики и прикладной математики Национального исследовательского, научный руководитель НОЦ КМ им. А.Б. Золотова Московского государственного строительного университета; профессор кафедры «Строительные конструкции, здания и сооружения〉 Российского университета транспорта (МИИТ); 125040, Россия, Москва, ул. 3-я Ямского Поля, д.18, офис 810; тел. +7 (499) 706-88-10. E-mail: amb@stadyo.ru

Горячевский Олег Сергеевич, ведущий инженер-расчетчик ЗАО Научно-исследовательский центр СтаДиО; заместитель директора НОЦ КМ им. А.Б. Золотова Национального исследовательского Московского государственного строительного университета; 129337 , Россия, г. Москва, Ярославское шоссе, д. 26. E-mail: osgoryachevskij@mail.ru

Бритиков Никита Александрович, инженер НОЦ КМ им. А.Б. Золотова Национального исследовательского Московского государственного строительного университета; аспирант Российского университета транспорта (МИИТ); 129337, Россия, г. Москва, Ярославское шоссе, д. 26. E-mail: n.a.britikov@gmail.com 